\title{
Carotenoids, Flavonoids, Total Phenolic Compounds and Antioxidant Activity of Two Creeping Cotoneaster Species Fruits Extracts
}

\author{
DAN RAZVAN POPOVICIU1, TICUTA NEGREANU-PIRJOL ${ }^{2,1 *}$, LUDMILA MOTELICA ${ }^{3}$, \\ BOGDAN STEFAN NEGREANU PIRJOL ${ }^{2}$ \\ ${ }^{1}$ Ovidius University of Constanta, Faculty of Natural Sciences and Agricultural Sciences, 1 University Alley, Campus, Corp \\ B, 900470, Constanța, Romania \\ ${ }^{2}$ Ovidius University of Constanta, Faculty of Pharmacy, 1 University Alley, Campus, Corp B, 900470, Constanta, Romania \\ ${ }^{3}$ University Politehnica of Bucharest, Faculty of Applied Chemistry and Materials Science, 1-7 Gh. Polizu, 011061, \\ Bucharest, Romania
}

\begin{abstract}
Cotoneaster horizontalis Decne. and Cotoneaster microphyllus Wall. ex Lindl. species are two creeping bushes, commonly used as ornamental plants in gardens and parks. The aim of this paper was to assess the concentrations of some classes of bioactive compounds classes, carotenoids, flavonoids and total phenolic compounds, in fresh fruits of these species. Carotenoids and flavonoids were determined through acetone and methanol extraction followed by spectrophotometry. For total phenolics, methanol extraction and a spectrophotometric Folin-Ciocâlteu method was used. The total antioxidant capacity was quantified through photochemiluminescence method by comparison with the standard substance used for calibration, Trolox ${ }^{\circledR}$ as tocopherol analogue (ACL procedure) using Photochem apparatus, Analytik Jena AG, Germany. Average values found in Cotoneaster horizontalis and Cotoneaster microphyllus fruit tissue were $380.63 \mathrm{mg} / \mathrm{kg}$, respectively $179.63 \mathrm{mg} / \mathrm{kg}$, carotenoids; $8036.07 \mathrm{mg} / \mathrm{kg}$, respectively $6888.06 \mathrm{mg} / \mathrm{kg}$ flavonoids; and $16342.06 \mathrm{mg} / \mathrm{kg} \mathrm{GAE}$, respectively $18631.35 \mathrm{mg} / \mathrm{kg}$ GAE total phenolic compounds. These values are comparable to those found in other wild and cultivated related Rosaceae, including domestic rowans. Cotoneaster microphyllus fruits emphasized an increased antioxidant activity (up to $39.69 \mu \mathrm{mol}$ Trolox equivalent/g dry weight).
\end{abstract}

Keywords: Cotoneaster horizontalis, Cotoneaster microphyllus, carotenoids, flavonoids, phenolic compounds, antioxidant activity

\section{Introduction}

Cotoneaster is a genus of Rosaceae (Amygdaloideae subfamily, Maleae tribe), comprising 70-300 species worldwide. All species are woody (shrubs and small trees), most being native to West China and the Himalayan region. Cotoneasters are now widely grown as ornamental plants throughout the world, due to their attractive evergreen or semi-evergreen foliage and their dense and bright-colour fruits. Some of them are also increasingly common in Romania, including prostrate species, commonly known as "rocksprays"

Cotoneaster horizontalis Decne. (wall/rock cotoneaster, rockspray, wall-spray), is a dwarf shrub, less than $1 \mathrm{~m}$ tall, with long prostrate branches, numerous lateral twigs (Figure 1). Leaves are small, elliptic, semi-deciduous and glossy with a rounded apex. White-pink flowers are grouped in compact inflorescences and fruits are small, globosely, bright-red pomes. It is native to Western of China, and grown in parks and gardens throughout temperate areas, including Romania. In some areas of the world, it is considered invasive [1].

Cotoneaster microphyllus Wall. ex Lindl. (small-leaf/little leaf cotoneaster, rockspray) is a dwarf shrub, less than $1 \mathrm{~m}$ tall, with extensive horizontal branches and twigs (Figure 1). It is a native of Tibet,

*email: ticuta_np@yahoo.com 
Yunnan, Sichuan and Nepal. There are four varieties: cochleatus, conspicuus, glacialis and thymifolius. Ornamental cultivars grown in Romania belong to Cotoneaster microphyllus var. cochleatus. Leaves are small, elliptic and evergreen, with an obtuse apex. Flowers are white and solitary, or grouped in small clusters. Fruits are small, globosely, bright-red pomes [2].

Cotoneaster fruits are known as mildly toxic, due to their cyanogenic glycoside content. Through digestion, these glycosides are converted to toxic cyanide. However, the concentration is too low to produce effects in adults. A large raw consumption would lead to brain, heart, kidney or liver illness. In some regions, cotoneaster berries are used for jellies or as a colorant. Known folk medicinal uses of Cotoneaster microphyllus fruits include, anti-irritant pastes for skin care and oral treatments for biliary dysfunction and irregular menstruation [2]. Also, the fruits of other Cotoneaster species have various applications in folk medicine, against infections, vascular diseases, bronchitis or gastritis [3].

The aim of this paper is to determine the concentrations of some key classes of phytochemicals in fresh fruit tissue of Cotoneaster horizontalis Decne. and Cotoneaster microphyllus Wall. ex Lindl. species.

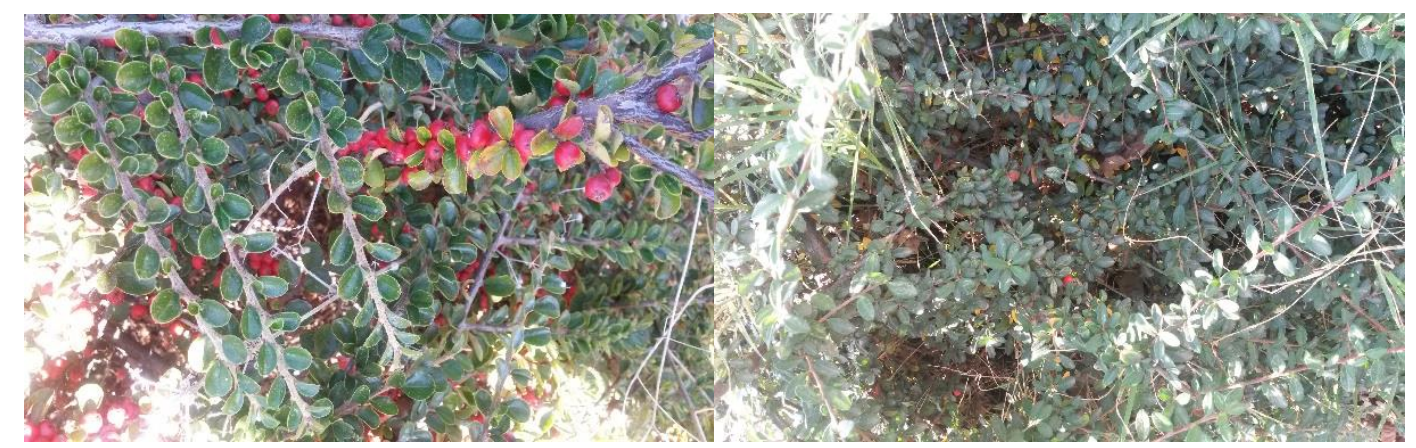

Figure 1. Cotoneaster horizontalis Decne. and Cotoneaster microphyllus Wall. ex Lindl.

Carotenoids (carotenes, lutein, lycopene, zeaxanthin etc.) are common pigments in plant leaves, flowers and fruits. They are essential for melanin and retinol production, thus, for skin and eye health, while they also possess antitumor properties [4].

There are various subclasses of phenolic and polyphenolic compounds, with protective functions against microbial and fungal pathogens and insects [5]. Among them, flavonoids, phenolic acids, tannins. These compounds are antioxidants, acting as radical scavengers, reducing agents and lipid oxidation inhibitors [6]. Flavonoids (low-mass polyphenolic compounds) are antiviral, antibacterial, antifungal, anti-inflammatory, antiproliferative and antitumor compounds [5].

\section{Materials and methods}

Mature pomes from different individuals from both species were collected in Constanța city, Romania, in October - November months, 2018. Pyrenes (kernels) were manually eliminated and the fruit pulp was ground, using an electrical grinder. Fruit tissue was kept frozen $\left(-20^{\circ} \mathrm{C}\right)$, prior to examination. Part of the material was oven-dried for $72 \mathrm{~h}$ at $80^{\circ} \mathrm{C}$, for determining dry biomass percentage.

For determining total carotenoids content, $0.1 \mathrm{~g}$ ground fruit tissue was extracted in $10 \mathrm{~mL} 80 \%$ acetone (triplicate samples for each species). The extract was filtered at normal pressure through Whatman blue band filter paper and the spectrophotometric absorbance was read (using a S106 WPA UV-Vis spectrophotometer) against an $80 \%$ acetone blank, at $470 \mathrm{~nm}, 647 \mathrm{~nm}$ and $663 \mathrm{~nm}$ of wavelengths [7]. Absorbance values were used to calculate carotenoids concentration, according to the specific trichromatic equations [8].

For flavonoid determinations, a quantity of $1 \mathrm{~g}$ ground fruit tissue was extracted in $5 \mathrm{~mL}$ methanol and filtered (triplicate samples). $0.5 \mathrm{~mL}$ of extract was diluted in $4 \mathrm{~mL}$ water and $8 \mathrm{~mL}$ methanol mixture, and the spectrophotometric absorbance was read against a methanol blank at $340 \mathrm{~nm}$ wavelength [9]. 
For determining the concentration of total phenolic compounds, a UV-Vis spectrophotometric version of the Folin-Ciocâlteu method was used. $0.1 \mathrm{~g}$ fruit tissue was extracted in $10 \mathrm{~mL}$ methanol and filtered. $1 \mathrm{~mL}$ of extract was reacted with $5 \mathrm{~mL}$ Folin-Ciocalteu reagent (10\%) and $4 \mathrm{~mL}$ sodium bicarbonate solution (7.5\%) for $30 \mathrm{~min}$. Spectrophotometric absorbance was read against a blank at 765 nm. A calibration curve was prepared, by using different gallic acid concentrations [10 - 12]. Concentrations were expressed as $\mathrm{mg} / \mathrm{kg}$ dry weight and $\mathrm{mg} / \mathrm{kg}$ DW gallic acid equivalent (GAE) for total phenolic compounds.

For determining total antioxidant capacity, a quantity of $1 \mathrm{~g}$, respectively $10 \mathrm{~g}$ of fine dried fruit powder, was cold-extracted in $40 \%$ ethanol (100 mL total volume), at room temperature and darkness, for 12 days, with regular shaking. After decantation, normal pressure filtration and homogenization (Vortex Velp Scientifica, Italy agitator), $10 \mu \mathrm{L}$ of supernatant were taken for analysis. Each determination lasted $120 \mathrm{~s}$.

Analyses employed the photochemiluminescence method by ACL (Antioxidative Capacity in Lipid Soluble Substances) procedure Analytik Jena and Photochem apparatus Analytik Jena AG, Germany. Triplicate samples of hydroalcoholic extract were quantified by comparison with the standard substance Trolox ${ }^{\circledR}$, Hoffman-LaRoche's trade name (6-hydroxy-2,5,7,8-tetramethylchroman-2-carboxylic acid) vitamin E derivative.

For calibration, the standard kit of reagents, Analytik Jena Germany was used: $\mathrm{R}_{1}$ (dilution solvent), $\mathrm{R}_{2}$ (buffer reagent), $\mathrm{R}_{3}$ (photosensitive reagent), $\mathrm{R}_{4}$ (reagent sized). For the calibration curve (Figure 2) standard solutions containing 0.5, 1.0, 2.0, $3.0 \mathrm{nmol}$ Trolox were measured (suitable for $5-30 \mu \mathrm{L} \mathrm{R}_{4}$ ). By exposure to external radiation from a Hg lamp lined with phosphorus, maximum energy at $351 \mathrm{~nm}$ wavelength, the photosensitive reagent produces free radicals in the sample, resulting a photochemical reaction. The superoxide anion radicals produced are partially neutralized by reaction with the antioxidants in the sample. Residual radicals cause luminescence in the detector substance, which can be determined using a photomultiplier tube. The signal produced by the luminescence is traced over 3 min.

The total antioxidant capacity of the selected sample is measured by converting the electrical signal to concentration values and by comparison with the Trolox ${ }^{\circledR}$ standard substance, expressed as nmol Trolox equivalents/sample volume $[13,21,22]$. Samples were prepared, according to Table 1.

Table 1

Working scheme volumes, $\mu \mathrm{L},[21,22]$

\begin{tabular}{|cccccc|}
\hline Kit reagent & $\mathrm{R}_{1}$ & $\mathrm{R}_{2}$ & $\mathrm{R}_{3}$ & $\mathrm{R}_{4}$ & Sample \\
\hline Blank & 2300 & 200 & 25 & 0 & 0 \\
\hline Calibration curve & $2300-$ vol. & 200 & 25 & vol. & 0 \\
\hline Measurement sample & $2300-$ vol. & 200 & 25 & 0 & ol. \\
\hline
\end{tabular}

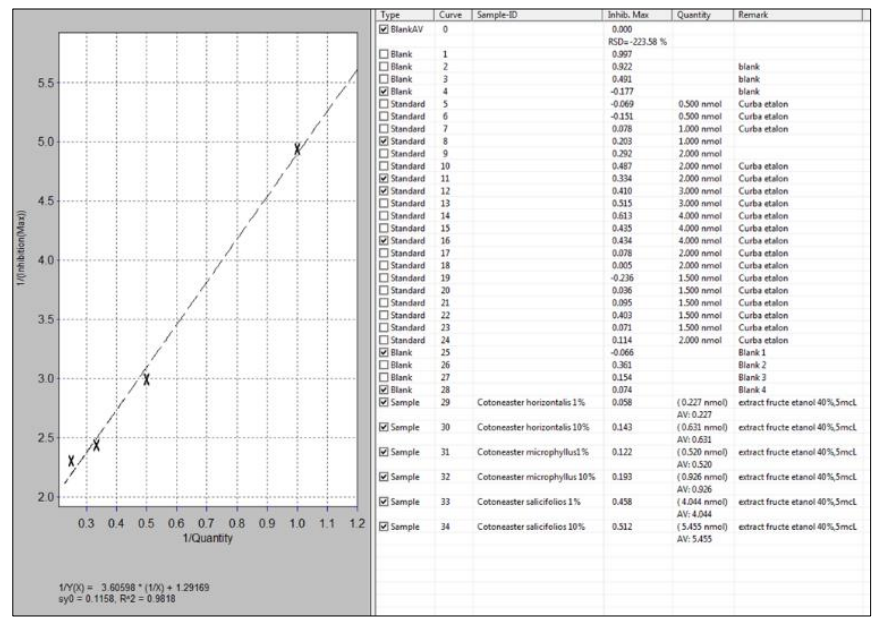

Figure 2. Calibration curve for standard substance Trolox ${ }^{\circledR}$ (photochemiluminescence method, ACL procedure, Analytik Jena AG) 


\section{Results and discussions}

Carotenoids concentrations in the selected fruits are shown in Figure 3. Flavonoids and total phenolic compounds level are shown in Figure 4 and Figure 5, respectively.

Considering a $13.1 \%$ dry weight percentage, the average amount of total carotenoids was 380.63 $\mathrm{mg} / \mathrm{kg}$ DW (315.47 - $433.62 \mathrm{mg} / \mathrm{kg}$ in individual samples), in Cotoneaster horizontalis and 179.63 $\mathrm{mg} / \mathrm{kg}$ DW $(165.57-189.83 \mathrm{mg} / \mathrm{kg}$ ) in Cotoneaster microphyllus (Figure 3). Few data concerning the carotenoids content of Cotoneaster species are found in literature. An useful comparison standard would be the related genus Pyracantha containing over $65 \mathrm{mg} / \mathrm{kg}$ carotenoids in Pyracantha angustifolia [14], and more than $22 \mathrm{mg} / \mathrm{kg}$ in Pyracantha crenulata species (known as a valuable medicinal plant, powdered dried fruits used in the treatment of bloody dysentery) $[15,19]$.

Sorbus (the genus comprising rowanberries and service-trees), is also a related genus, in the Maleae tribe, with similar fruits. A comprehensive research on cultivated rowan varieties found a total carotenoid content of $39-2659 \mathrm{mg} / \mathrm{kg}$ [6].

An average of $8036.07 \mathrm{mg} / \mathrm{kg}$ DW of flavonoids $(4,457-10,940 \mathrm{mg} / \mathrm{kg})$ was found in Cotoneaster horizontalis fruit tissue. Cotoneaster microphyllus fruit tissue contained $6888.06 \mathrm{mg} / \mathrm{kg}$ DW flavonoids (3444 - $10332 \mathrm{mg} / \mathrm{kg}$ ), Figure 4. These values are similar to those found by Mohamed et al. in Cotoneaster horizontalis fruits $(6800 \mathrm{mg} / \mathrm{kg})$ [1], lower than in Cotoneaster multiflorus fruits (53700 $\mathrm{mg} / \mathrm{kg}$ ) [3].

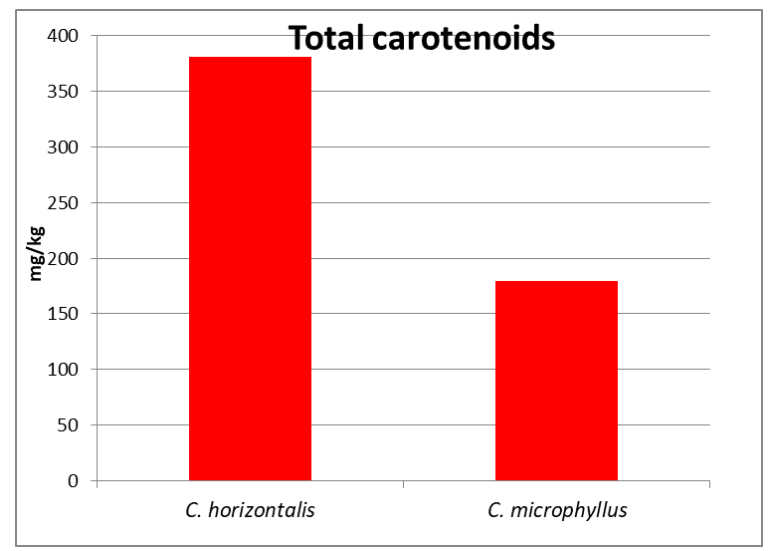

Figure 3. Total carotenoids concentration in selected Cotoneaster species fruits (average values; $\mathrm{mg} / \mathrm{kg}$ )

Fruits of Sorbus species contain 435 - $37000 \mathrm{mg} / \mathrm{kg}$, with high variations due to species, variety, ripening stage, or local factors $[6,15]$.

The total concentration of phenolic and polyphenolic compounds (including flavonoids) averaged $16342.06 \mathrm{mg} / \mathrm{kg}$ GAE (DW; 14983 - $17558 \mathrm{mg} / \mathrm{kg}$ ) in Cotoneaster horizontalis and $18631.35 \mathrm{mg} / \mathrm{kg}$ GAE (DW; 18417 - $18846 \mathrm{mg} / \mathrm{kg}$ ) in Cotoneaster microphyllus (Figure 5). These values are similar to those found in Cotoneaster horizontalis fruits (14000 mg/kg GAE) in a previous study [1] and lower than those in Cotoneaster multiflorus (38600 mg/kg GAE) [3].

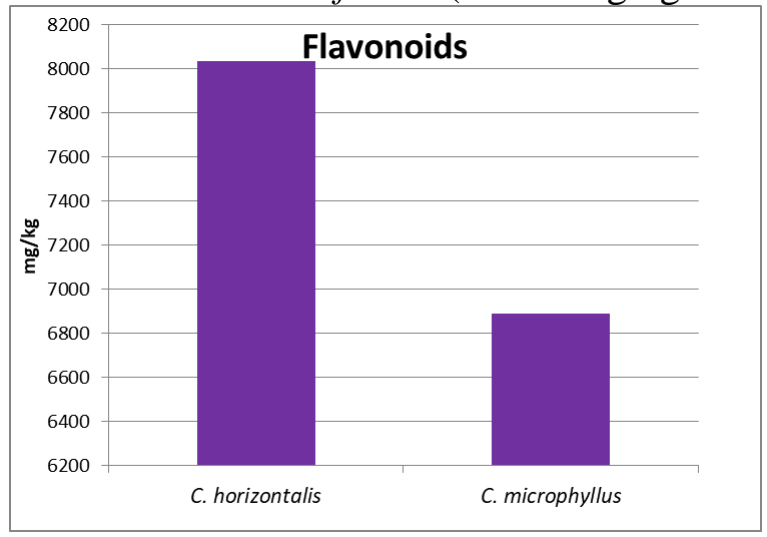

Figure 4.

Total flavonoids concentration in selected Cotoneaster species fruits (average values; $\mathrm{mg} / \mathrm{kg}$ ) 
For comparison, the related Pyracantha crenulata species contains $7430 \mathrm{mg} / \mathrm{kg}$ total phenolics in fruits [15]. More than $10000 \mathrm{mg} / \mathrm{kg}$ were found in Sorbus domestica fruits [16], and $19150 \mathrm{mg} / \mathrm{kg}$ in Sorbus torminalis fruits [17]. A study on other domestic cultivars of Sorbus species found $362-8142$ $\mathrm{mg} / \mathrm{kg}$ GAE [6] while 2218 - $9843 \mathrm{mg} / \mathrm{kg} \mathrm{GAE}$ were found in wild forms [18].

Total antioxidant capacity (TEAC) of fruits pulp hydroalcoholic extracts was reported according to the photochemiluminescence method, ACL procedure of Analytik Jena AG and quantified by comparison with Trolox ${ }^{\circledR}$ standard substance. Results are shown in Table 2.

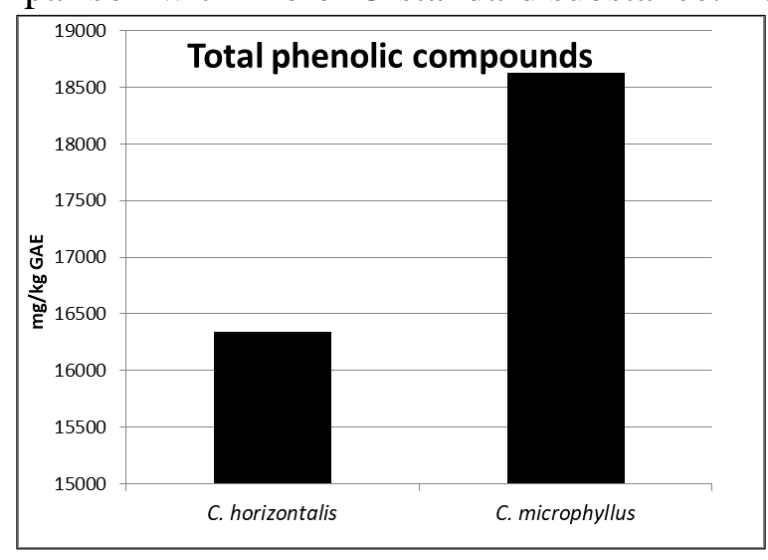

Figure 5. Concentration of total phenolic compounds in selected Cotoneaster species fruits (average values; $\mathrm{mg} / \mathrm{kg}$ )

For both species, $10 \%$ extracts yielded significantly higher antioxidant capacities than $1 \%$ extracts (178\% higher, for Cotoneaster horizontalis and $78 \%$ higher for Cotoneaster microphyllus pomes). However, when reported to initial fruits biomass, $1 \%$ extraction proved more efficient [23-30].

Table 2

Total antioxidant capacity (TEAC) of Cotoneaster fruits hydroalcoholic extracts

\begin{tabular}{ccccccc}
\hline No. & Sample Type & $\begin{array}{c}\text { Extraction } \\
\text { time } \\
\text { (days) }\end{array}$ & $\begin{array}{c}\text { Working } \\
\text { volume }(\mu \mathrm{L})\end{array}$ & $\begin{array}{c}\text { Analysis } \\
\text { time } \\
(\mathrm{sec} .)\end{array}$ & $\begin{array}{c}\text { Free radicals } \\
\text { Inhibition Max. }\end{array}$ & $\begin{array}{c}\text { Quantity means } \\
\text { (TEAC) } \\
(\mu \text { mol equiv. } \\
\text { Trolox/g tissue) }\end{array}$ \\
\hline $1 . \quad \begin{array}{c}\text { Cotoneaster horizontalis 1\% in } \\
\text { ethyl alcohol 40\% }\end{array}$ & 12 & 10 & 120 & 22.70 & 2.27 \\
$(17.33 \mathrm{DW})$
\end{tabular}

Considering the initial dry biomass, the maximum antioxidant activity of Cotoneaster horizontalis fruits pulp tissue was $17.33 \mu \mathrm{mol} / \mathrm{g}$, while that of Cotoneaster microphyllus was higher, $39.69 \mu \mathrm{mol} / \mathrm{g}$.
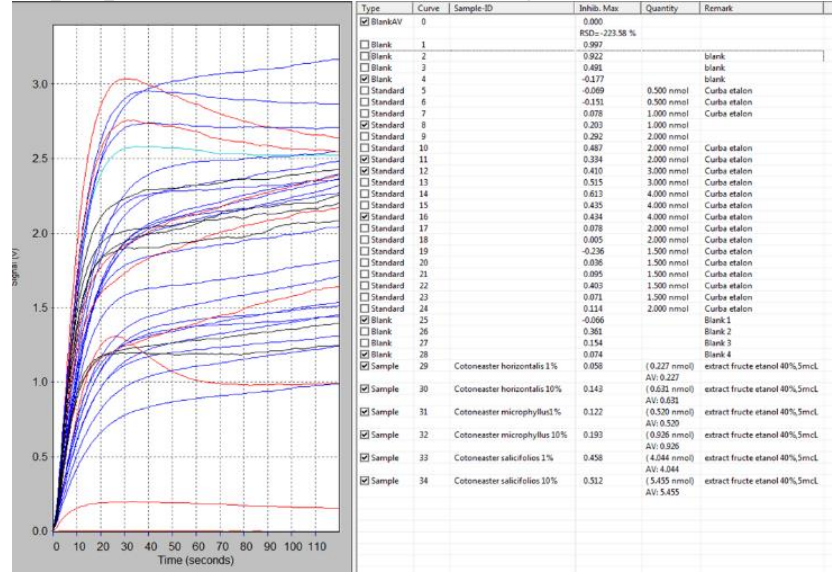

Figure 6. ACL procedure curves for Cotoneaster horizontalis and Cotoneaster microphyllus fruit extracts samples 
A close relative of Cotoneasters species is the medicinal plant Pyracantha crenulata. Its fruits were found to yield 13.00 - $32.98 \mu \mathrm{mol}$ Trolox equivalent/g antioxidant capacity [15].

Higher values were found in rowanberries (Sorbus species), $49.00-476.00 \mu \mathrm{mol}$ Trolox equivalent/g [6].

\section{Conclusions}

Having average contents of $380.63 \mathrm{mg} / \mathrm{kg}$, respectively, $179.63 \mathrm{mg} / \mathrm{kg}$, Cotoneaster horizontalis Decne. and Cotoneaster microphyllus Wall. ex Lindl. species fruits were similar to related Rosaceae fruits, including Sorbus cultivars, and could be a valuable source of vitamin A and other important carotenoid-derived compounds.

With $8036.07 \mathrm{mg} / \mathrm{kg}$, respectively $6888.06 \mathrm{mg} / \mathrm{kg}$ flavonoids content, they were also comparable to Sorbus species and other wild and cultivated Rosaceae. The same can be said for total phenolic and polyphenolic compounds content (16342.06 mg/kg GAE, respectively $18631.35 \mathrm{mg} / \mathrm{kg}$ GAE).

While the concentration of phenolic compounds (including flavonoids) was similar in the two species, the amount of carotenoids was significantly higher in Cotoneaster horizontalis pomes.

With up to $39.69 \mu \mathrm{mol}$ Trolox equivalent/g DW, the total antioxidant capacity of Cotoneaster microphyllus pomes is increased, and similar to that of some related medicinal and nutrition-use Rosaceae species.

Further research is needed to assess, in detail, the composition in bioactive compounds and to confirm the potential of these vegetal species for valuable applications other than ornamental ones.

Acknowledgement: This work was supported by a grant of the Romanian Ministry of Research and Innovation, CCCDI - UEFISCDI, project number PN-III-P1-1.2-PCCDI-2017-0689 /P1. „Lib2Life Revitalizarea bibliotecilor si a patrimoniului cultural prin tehnologii avansate" within PNCDI III

\section{References}

1.MOHAMED, S.A., SOKKAR, N.M., EL-GINDI, O., ALI, Z.Y., ALFISHAWY, I.M., Life Sci. J., 9, no. 2, 2012, p. 394.

2.SWATI, S., MANJULA, R.R., SOWJANYA, K., VENNELA, Y., TANUJA, K., J. Pharm. Sci. Res., 10, no. 9, 2018, p. 2166.

3.LIU, X., JIA, J., JING, X., LI, G., J. Chem. (Hindawi), 2018, 2018, DOI: 10.1155/2018/4619768.

4.SULTANA, S., ALI, M., MIR, S.R., J. Pharm. Biol. Sci., 5, no. 3, 2017, p. 91.

5.BUTNARIU, M., SARAC, I., PENTEA, M., SAMFIRA, I., NEGREA, A., MOTOC, M., BUZATU, A.R., CIOPEC, M., Rev. Chim., 67, 3, 2016, 503.

6.KIVRAK, I, KIVRAK, S., Austin J. Nutr. Food Sci., 2, no. 8, 2014, p. 1043.

7.ZYMONĖ, K., RAUDONE, L., RAUDONIS, R., MARKSA, M., IVANAUSKAS, L., JANULIS, V., Molecules, 23, 2018, p. 2593.

8.POPOVICIU, D.R., NEGREANU-PIRJOL, T., MICLAUS, L.S., Rev. Chim., 68, (1), 2017, 40.

9.LICHTENTHALER, H.K., BUSCHMANN, C., Curr. Protoc. Food Anal. Chem., 2001, F4.3.1. p.1.

10.SZABO, I., VONHAZ, G., FODOR, A., BUNGĂU, S., ȚIT,, D.M., Analele Universitatii din Oradea, Fascicula Protecția Mediului, 18, 2012, p. 73.

11.STANKOVIC, M.S. Kragujevac J. Sci., 33, 2011, p. 63.

12.STANKOVIC, M.S., NICIFOROVIC, N., TOPUZOVIC, M., SLAVICA SOLUJIC, S., Biotechnol. \& Biotechnol. Eq., 25, 2011, DOI: 10.5504/bbeq.2011.0020.

13.PALlAG, A., JURCA, T., SIRBU, V., HONIGES, A., JURCA, C., Rev. Chim., 69, (2), $2018,445$. 14.POPOV, I., LEWIN, G., Methods in Enzymology, 300, Part B, Oxidants and Antioxidants, Ed. Lester Packer, Academic Press, New York, 1999, p. 437.

15.ZECHMEISTER, L. SCHROEDER, W.A., J. Biol. Chem., 144, 1942, p. 315. 
16.PAL, R.S., KUMAR, R.A., AGRAWAL P.K., BHATT, J.C., Int. J. Pharm. Bio. Sci., 4, no. 2, 2013, p 113.

17.MAJIC B., SOLA I., LIKIC S., JURANOVIC CINDRIC I., RUSAK G., Food Technol. Biotechnol., 53, no. 4, 2015, p. 463.

18.HASBAL, G., YILMAZ-OZDEN, T., CAN, A., J. Food Drug Anal., 23, 2015, p. 57.

19.RAUDONIS R., RAUDONE L., GAIVELYTE K, VISKELIS P., JANULIS V., Nat. Prod. Res., 28, no. 16, 2014, DOI: 10.1080/14786419.2014.895727.

20.MANANDHAR, N. P., Plants and People of Nepal, Timber Press, Oregon, 2002.

21.NEGREANU-PIRJOL, T., NEGREANU-PIRJOL, B.-S., POPESCU, A., BRATU, M.M., UDREA, M., BUSURICU, F., Journal of Environmental Protection and Ecology, 15, no. 3, 2014, p. 1139 - 1148. 22.NEGREANU-PIRJOL, B.-S., NEGREANU-PIRJOL, T., BRATU, M., POPESCU, A., RONCEA, F., MIRESAN, H., JURJA, S., PARASCHIV, G.M., $14^{\text {th }}$ International Multidisciplinary Scientific GeoConferences „Surveying Geology \& mining Ecology Management - SGEM 2014”, 17 - 26 June 2014, Albena, Bulgaria, Conference Proceedings, Vol. I, Section: Advances in Biotechnology, p. 239 244, DOI: 10.5593/sgem2014B61.

23.LACATUSU, I., BADEA, N., MURARIU, A., OPREA, O., BOJIN, D., MEGHEA, A., Soft Materials, 11, no. 1, 2013, p.75

24.MAlAERU, T., PATROI, E.A., MARINESCU, V., OPREA, O., PATROI, D., MORARI, C., MANTA, E., GEORGESCU, G., Rev. Chim.,70, (2), 2019, 459.

25.NEGREANU-PIRJOL, B.-S., NEGREANU-PIRJOL, T., SIRBU, R., POPOVICIU, D.R., Rev. Chim., 70, (2), 2019, 602.

26.NICULAE, G., BADEA, N., MEGHEA, A., OPREA, O., LACATUSU, I., Photochemistry and Photobiology, 89, no. 5, 2013, p. 1085

27.RADUlESCU, M., FICAI, D., OPREA, O., FICAI, A., ANDRONESCU, E., HOLBAN, A.M., Current Pharmaceutical Biotechnology, 16, no. 2, 2015, p. 128

28.LACATUSU, I., NICULAE, G., BADEA, N., STAN, R., POPA, O., OPREA, O., MEGHEA, A., Chemical Engineering Journal, 246, 2014, p. 311

29.LACATUSU, I., BADEA, N., BADEA, G., OPREA, O., MIHAILA, M.A., KAYA, D.A., STAN, R., MEGHEA, A., Materials Science and Engineering C, 56, 2015, p. 88

30.STAN, R.L., SEVASTRE, B., HANGAN, A.C., BOTA, S., HANGANU, D., IONESCU, C.M.L., POPOVICI, H., SEVASTRE-BERGHIAN, A.C., DREANCA, A., VICAS, L.G., Rev. Chim., 70, (6), 2019, 1903.

Manuscript received: 28.08 .2019 